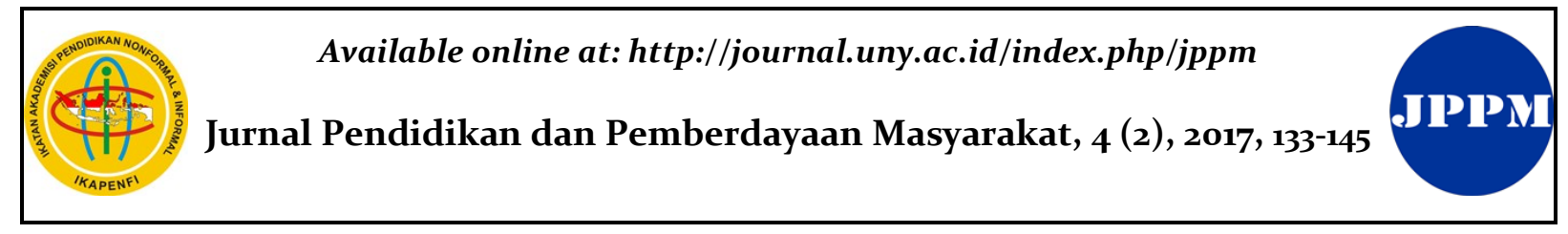

\title{
Implementasi Program Desa Vokasi Berbasis Pelatihan Kewirausahan Tata Boga
}

\author{
Norma Laili Ikhsan \\ Sekolah Kejar Paket Sembodo. Jalan Lapangan No 4, Sumpiuh, Banyumas, Jawa Tengah \\ Korepsondensi Penulis Email: norma.ikhsandira@gmail.com \\ Received: 17 February 2016; Revised: 27 October 2017; Accepted: 17 November 2017
}

\begin{abstract}
Abstrak
Tujuan penelitian ini adalah untuk mengetahui (1) Implementasi program pelatihan kewirausahaan tata boga di Desa Vokasi Grujugan; (2) Penilaian hasil; (3) Faktor pendukung dan penghambat kegiatan usaha, dan (4) Dampak program. Penelitian ini menggunakan pendekatan deskriptif kualitatif. Subjek penelitian adalah pengelola, tutor, peserta didik di Desa Vokasi Grujugan. Pengumpulan data menggunakan metode observasi, wawancara, dokumentasi. Teknik analisis data melalui reduksi data, penyajian data, dan penarikan kesimpulan. Hasil penelitian mengungkapkan sebagai berikut. (1) Implementasi program pelatihan terdiri atas empat tahap yaitu persiapan, pelaksanaan, monitoring dan evaluasi, dan tindak lanjut. (2) Penilaian hasil pelatihan menunjukan terjadi perubahan sikap peserta didik dalam menjalankan kegiatan usaha mandiri. (3) Faktor mendukung meliputi motivasi; perencanaan yang baik; pendampingan usaha yang baik; dan kemampuan mengenal peluang, kesempatan. Faktor penghambat meliputi kurangnya pengalaman, kemampuan manajerial dan SDM; kurangnya modal, kemampuan mengatur aliran kas dan kemampuan dalam menghadapi resiko. (4) Dampak pelaksanaan program, meliputi: peningkatan ketrampilan (SDM), kemampuan berwirausaha, peningkatan status sosial, peningkatan aspek sosial ekonomi.
\end{abstract}

Kata kunci: implementasi program, pelatihan, kewirausahaan, desa vokasi.

\section{The Implementation of the Vocational Village Program Based on Culinary Entrepreneurship Training}

\begin{abstract}
The purpose of this study was to determine (1) The implementation of entrepreneurship training program in the village of vocational culinary Grujugan; (2) The ratings results; (3) The factors supporting and hindering business activity, and (4) The impact of the program. This study used a qualitative descriptive approach. Subjects were managers, tutors, learners in vocational Grujugan village. The data collection using the method of observation, interviews, documentation. Mechanical analysis of data through data reduction, data presentation, and conclusion. Results of the study revealed the following. (1) The Implementation of the training program consists of four phases: preparation, implementation, monitoring and evaluation, and follow-up. (2)The ratings training results indicate a change in attitudes of learners in running an independent business. (3) The factors include motivational support; good planning; Good business assistance; and the ability to recognize an opportunity, a chance. Inhibiting factors include a lack of experience, managerial ability and resources; lack of capital, the ability to manage cash flow and ability to face risks. (4) The impact of the implementation of the program, including: increasing the skills (human resources), entrepreneurship skills, increase social status, improvement of socio-economic aspects.
\end{abstract}

Keywords: implementation program, training, entrepreneurship, vocational villages.

How to Cite: Ikhsan, N. (2017). Implementasi program desa vokasi berbasis pelatihan kewirausahan tata boga.JPPM (Jurnal Pendidikan dan Pemberdayaan Masyarakat), 4(2), 133-145. doi:http://dx.doi.org/10.21831/jppm.v4i2.8047

Permalink/DOI: http://dx.doi.org/10.21831/jppm.v4i2.8047 


\section{Jurnal Pendidikan dan Pemberdayaan Masyarakat, 4 (2), November 2017 - 134}

Norma Laili Ikhsan

\section{PENDAHULUAN}

Kemiskinan merupakan masalah pembangunan yang ditandai dengan pengangguran, keterbelakangan, dan keterpurukan. Kemiskinan adalah suatu keadaan dimana seseorang tidak sanggup untuk memelihara dirinya sendiri yang sesuai dengan kehidupan kelompoknya dan juga tidak mampu untuk memanfaatkan tenaga mental maupun fisiknya dalam kelompok itu (Syarbaini, Rahman, Djihado, Siagian, \& Suryana, 2002, p. 21). Berdasarkan data Susenas BPS (September, 2013), jumlah penduduk miskin juga masih cukup tinggi di Indonesia, yaitu sebesar 28,55 juta jiwa atau sebesar $11,47 \%$ dari total penduduk Indonesia (Kementerian pendidikan dan Kebudayaan, 2014, p. 1).

Jumlah kemiskinan itu terjadi antara lain disebabkan oleh potensi sumber daya alam khususnya di desa tidak diolah oleh tenaga muda yang produktif sehingga terlantar dan pembangunan di desa stagnan, yang disebabkan tingginya perpindahan tenaga kerja muda di perdesaan yang mencari lapangan kerja di kota (urbanisasi meningkat). Indonesia memiliki sekitar 78.609 desa, terdiri atas 70.390 administrasi desa dan 8.083 administrasi kelurahan yang tersebar diseluruh nusantara dengan keanekaragaman kekayaan sumber daya alam yang melimpah baik di sektor pertambangan, pariwisata, pertanian, kehutanan, perkebunan dan lain sebagainya. Jika sumber daya tersebut dapat diolah dan dimanfaatkan, maka dapat membuka sebuah akses lapangan pekerjaan di perdesaan dan bisa menekan laju perpindahan penduduk dari desa ke kota.

Selain kemiskinan disebabkan oleh tidak bisanya tenaga muda mengelola potensi sumber daya alam, pengangguran juga salah satu faktor penyebab kemiskinan. Berdasarkan data Sakernas BPS (Agustus, 2013) jumlah angka penganggur terbuka di Indonesia sebesar 7,4 juta jiwa atau 6,25 \% dari jumlah angkatan kerja sebesar 118,2 juta jiwa (Kementerian pendidikan dan Kebudayaan, 2014, pp. 1-2). Jumlah pengangguran terbuka yang masih besar itu, jelas sangat mempengaruhi kemajuan bangsa Indonesia.

Melihat permasalahan tersebut pemerintah Provinsi Jawa Tengah terus berupaya menyelenggarakan berbagai jenis program pembangunan untuk menekan kemiskinan dan mengurangi jumlah pengangguran di wilayahnya. Hal itu dilakukan mengingat Provinsi Jawa Tengah sendiri memiliki luas wilayah 3,25 juta hektar dengan jumlah penduduk pada tahun 2013 sebanyak 33,264 juta jiwa (Proyeksi Sensus Penduduk 2013) terdiri atas laki-laki sebanyak 16,499 juta jiwa $(49,60 \%)$ dan perempuan 16,764 juta jiwa (50,40\%). Secara administratif, Provinsi Jawa Tengah terbagi dalam 29 kabupaten, 6 kota, 573 kecamatan, serta 7.809 desa dan 769 kelurahan.

Salah satu upaya yang dilakukan Provinsi Jawa Tengah untuk menekan kemiskinan dan mengurangi jumlah pengangguran di wilayahnya adalah melalui bidang pendidikan dengan memberikan pelatihan (pendidikan vokasi) berbasis kewirausahaan berwujud pembentukan desa vokasi yang di gerakan oleh Direktorat Pembinaan Kursus dan Pelatihan, Direktorat Jenderal Pendidikan Anak Usia Dini, Pendidikan Nonformal, dan Informal Kementerian Pendidikan dan Kebudayaan (Ditjen PAUDNI Kemdikbud). Desa Vokasi merupakan kawasan perdesaan yang mengembangkan berbagai layanan pendidikan keterampilan (vokasi) dan kelompok-kelompok usaha untuk menghasilkan sumberdaya manusia yang mampu menciptakan produk barang/jasa atau karya lain yang bernilai ekonomi tinggi, bersifat unik dengan menggali dan mengembangkan potensi desa yang memiliki keunggulan komparatif dan keunggulan kompetitif berbasis kearifan lokal. (Kementerian pendidikan dan Kebudayaan, 2014, pp. 7-8).

Pendidikan vokasi yang dimaksudkan disinini adalah pendidikan yang dirancang untuk mengembangkan keterampilan, kemampuan, pemahaman, sikap, kebiasaan kerjadan penghargaan, meliputi pengetahuan dan informasi yang dibutuhkan oleh pekerj auntuk masuk dan membuat kemajuan dalam pekerjaan (Asoegwu, 2004 dalam Uwameiye \& Osho (2011, p. 864). Desa vokasi adalah salah satu bentuk pembangunan pedesaan. Tujuan pembangunan pedesaan adalah untuk mengatasi kebutuhan sebagian besar penduduk dan memastikan pengurangan kemiskinan yang berkelanjutan dan 


\section{Jurnal Pendidikan dan Pemberdayaan Masyarakat, 4 (2), November 2017 - 135}

Norma Laili Ikhsan

mata pencaharian pedesaan (Nibeza, 2015, p. 105). Dengan pembentukan desa vokasi dimaksudkan untuk mengembangkan sumber daya manusia dalam spektrum perdesaan dengan pendekatan kawasan, yaitu kawasan perdesaan yang dilandasi oleh nilai-nilai budaya dengan memanfaatkan potensi lokal guna mengatasi kebutuhan sebagian besar penduduk dan memastikan pengurangan kemiskinan yang berkelanjutan danmata pencaharian perdesaan.

Program Desa Vokasi di Jawa Tengah sudah dimulai pada tahun 2009 dengan menunjuk 105 desa sebagai rintisan pelaksana desa vokasi dari 7.809 desa yang ada di Provinsi Jawa Tengah, (Tim Direktorat Pengembangan Kursus dan Pelatihan, 2011, p. 1). Desa Grujugan adalah salah satu desa di Kabupaten Banyumas yang terpilih untuk mengembangkan program rintisan desa vokasi dari tahun 2009 sampai tahun 2015 sekarang ini. Hal ini dikarenakan di Desa Grujugan terdapat banyak pengangguran yang sebagian besar adalah pemuda dan anak yang tidak melanjutkan sekolah. Berdasarkan data sensus penduduk 2008, (BPS Kabupaten Banyumas, 2008) total penduduk Kecamatan Kemranjen sebesar 3.483 jiwa yang terdiri atas 1.739 laki-laki dan 1.747 perempuan. Dan dari jumlah tersebut tercatat penduduk miskin sebanyak 344 jiwa dan pengangguran 627 jiwa. Berdasarkan hasil identifikasi diperoleh bahwa sebagian besar masyarakat belum memiliki keterampilan praktis produktif dan mudah dikembangkan, sehingga dapat dijadikan sumber penghasilan atau pekerjaan sampingan yang menghasilkan.

Berdasarkan hasil prasurvay, dalam pelaksanaan program Desa Vokasi Grujugan tahun 2009, Program Desa Vokasi Grujugan menyelenggarakan lima jenis pelatihan kewirausahaan yang meliputi pelatihan kewirausahaan menjahit, sablon, kerajinan keset, ternak itik, dan tata boga. Pada tahun 2010 sampai 2011 dalam pelaksanaan pelatihan kewirausahaan Desa Vokasi Grujugan hanya menyelenggarakan dua jenis keterampilan saja, yaitu pelatihan kewirausahaan tata boga, dan kerajinan keset, namun tahun 2011 ini pelatihan yang terlihat paling berkembang diantara kedua pelatihan yang diadakan di desa vokasi adalah pelatihan kewirausahaan tata boga. Dan dari tahun 2012 sampai 2015 program pelatihan kewirausahaan tata boga masih tetap berkembang dan selalu mendapatkan bantuan dana untuk penguatan manajemen vokasi tata boga.

Berdasarkan hasil prasurvay, dalam pelaksanaanya, pada tahun 2015 pelatihan kewirausahaan tata boga telah sampai pada proses kegiatan usaha mandiri sebagai upaya peserta didik dalam menerapkan ilmu yang mereka peroleh saat pelatihan. Dalam kegiatan usaha ini pihak penyelenggara memberikan bentuk pendampingan yang berupa pemberian modal usaha dan pembinaan dalam bentuk pengarahan kepada peserta didik dalam melaksanakan kegiatan usaha. Selain itu pengelola juga mengupayakan memberikan pelatihan lebih banyak olahan makanan dan mendapatkan berbagai program dukungan dari berbagai instansi seperti bantuan pembuatan P.IRT dari Disperindag agar produknya pemasarannya lebih luas, dan bantuan dari UNSOED dalam hal pelatihan pengemasan produk dan berbagai program.

Berdasarkan hasil prasurvay tersebut dapat terlihat bahwa dalam pelaksanaanya, program pelatihan kewirausahaan tata boga merupakan program yang paling lama berjalan dan mengalami pengembangan program pelatihan diantara program-program pelatihan kewirausahaan yang diadakan di DesaVokasi Grujugan. Hal inilah yang menarik penulis untuk dapat mengulas lebih dalam, untuk mengetahui bagaimana implementasi pelaksanaan pelatihan kewirausahaan tata boga, dari pelaksanaan kegiatan pembelajaran, dan praktik penerapan hasil pelatihan dalam bentuk kegiatan usaha mandiri. Karena itu penelitian ini ingin bermaksud mengetahui lebih dalam tentang implementasi program desa vokasi berbasis pelatihan kewirausahaan tata boga di Desa Vokasi Grujugan, Kecamatan Kemranjen, Kabupaten Banyumas.

\section{METODE}

Penelitian ini menggunakan penelitian kualitatif. Waktu penelitian dilaksanakan pada bulan September-November 2015, 


\section{Jurnal Pendidikan dan Pemberdayaan Masyarakat, 4 (2), November 2017 - 136 Norma Laili Ikhsan}

dengan tempat penelitian di Desa Vokasi Grujugan, Kecamatan Kemranjen, Kabupaten Banyumas, Provinsi Jawa Tengah.

Subjek penelitian dalam penelitian ini adalah orang yang terlibat dalam pelaksanaan program pelatihan kewirausahaan tata boga Desa Vokasi Grujugan yang meliputi: (1) penanggungjawab program yaitu Kepala Desa Grujugan; (2) pengelola program; (3) tutor pendidik; (4) peserta program.

Metode yang digunakan meliputi pengamatan atau observasi, wawancara, dandokumentasi. Teknik analisis data dalam penelitian ini dilakukan dalam empat tahapan menurut Miles \& Huberman dalam Pawito (2008, pp. 104-106), yang meliputi: (1) pengumpulan data; (2) reduksi data; (3) penyajian data; dan (4) penarikan kesimpulan. Teknik keabsahan data yang digunakan dalam penelitian ini adalah teknik triangulasi metode.

\section{HASIL DAN PEMBAHASAN}

\section{Pelaksanaan Program Pelatihan Kewirausahaan Tata Boga Desa Vokasi Grujugan}

Hasil penelitian menjelaskan dalam pelaksanaan pelatihan kewirausahaan tata boga Desa Vokasi Grujugan dibagi menjadi empat tahap, meliputi tahap yang dilakukan sebelum platihan (pra-pelatihan) yaitu tahapan persiapan. Tahap yang dilakukan saat proses pelatihan yaitu tahap kegiatan pembelajaran. Dan tahap yang dilakukan pasca pelatihan meliputi tahap monitoring\& evaluasi, dan tahap tindak lanjut. Untuk pelaksanaan tahap-tahap tersebut dijelaskan pada Gambar 1:

Tabel 1. Komponen Input Program Desa Vokasi

\begin{tabular}{|c|c|}
\hline $\begin{array}{c}\text { Koponen } \\
\text { Input }\end{array}$ & Hasil \\
\hline Warga & 20 orang (13 SD, 5 SMP, dan 2 \\
\hline Belajar & $\begin{array}{l}\text { SMA). Dan latar belakang pekerja- } \\
\text { an ibu rumah tangga, petani dan } \\
\text { pedagang). }\end{array}$ \\
\hline Nara & Ibu Ening dari SKB, Sarjana, meng- \\
\hline Sumber & $\begin{array}{l}\text { ajarkan teori dan kewirausahaan } \\
\text { dan pembuatan kue kering; } \\
\text { Tohirah, SMP, peserta didik yang } \\
\text { merangkap menjadi tutor karena } \\
\text { keahliannya dalam mengajarkan } \\
\text { pembuatan satu kacang ijo dan } \\
\text { sagon, Surifah, SMA ahli membuat } \\
\text { dan mengajarkan jipang dan } \\
\text { jajanan pasar yang dijadikan NS } \\
\text { praktek. }\end{array}$ \\
\hline Pengelola & $\begin{array}{l}\text { Ketua PKBM, } 1 \text { perwakilan aparat } \\
\text { desa, Kader PKK ( } 2 \text { SMA, } 1 \text { Sarjana) }\end{array}$ \\
\hline Pendanaan & Dana Block Green Rp. 15.00o.ooo,oo \\
\hline $\begin{array}{l}\text { Sarana dan } \\
\text { Prasarana }\end{array}$ & $\begin{array}{l}\text { Peralatan memasak seperti mixer, } \\
\text { oven, cetakan roti, wajan dan } \\
\text { peralatan memasak lainnya. }\end{array}$ \\
\hline
\end{tabular}

Sumber: Diolah dari data Primer, Tahun 2016

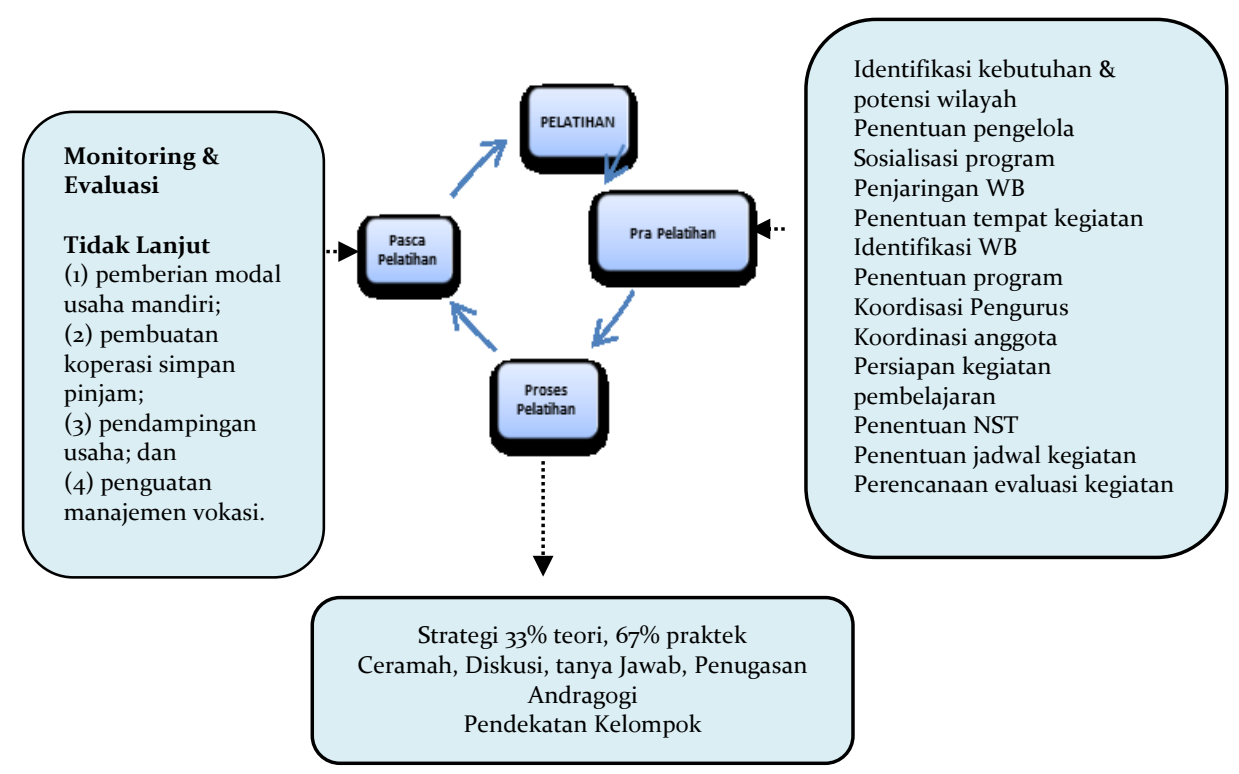

Gambar 1. Tahap Implementasi Palatihan Kewirausahaan Desa Vokasi 


\section{Jurnal Pendidikan dan Pemberdayaan Masyarakat, 4 (2), November 2017 - 137 Norma Laili Ikhsan}

Berdasarkan data Tabel 1 dapat dijelaskan bahwa komponen imput mendukung bagi kelancaran pelaksanaan program pelatihan kewirausahaan tata boga Desa Vokasi Grujugan.

Pada Gambar 1, hasil penelitian mengenai pelaksanaan program pelatihan kewirausahaan yang dikembangkan dalam program desa vokasi ini mampu diselenggarakan dengan baik dalam pra-pelatihan, proses pelatihan dan pasca pelatihan. Pada pra pelatihan, tahap ini meliputi tahap persiapan, pada proses pelatihan yang meliputi tahap pelaksanaan kegiatan pembelajaran; dan pada pasca pelatihan, tahap ini meliputi tahap monitoring dan evaluasi dan tahap tindak lanjut.

Pelaksanaan program pelatihan kewirausahaan yang dikembangkan dalam program desa vokasi ini mampu diselenggarakan dengan baik dalam pra-pelatihan, proses pelatihan dan pasca-pelatihan, Namun terdapat beberapa kelemahan dalam tahap pasca pelatihan yaitu pada proses tindak lanjut. Pemberian modal untuk kegiatan usaha mandiri yang seharusnya diberikan kepada peserta didik senilai Rp. 625.000,00 dipotong sebesar Rp. 375.00o,oo untuk mendirikan sebuah koperasi usaha kelompok tata boga, jadi modal bersih untuk kegiatan usaha yang diberikan kepada masing-masing peserta didik sebesar Rp. 250.000,00.

Menurut Situmorang (2011), suatu aktivitas bisnis tidak akan dapat berjalan dengan baik bila tidak didukung oleh ketersediaan dana yang baik dan mencukupi. Bila suatu aktivitas bisnis tidak dapat memenuhi permintaan barang atau jasa sesuai dengan jumlah dan kriteria pelanggan dikarenakan bisnis tersebut tidak memiliki dana yang cukup untuk melakukan proses produksinya, maka sudah dapat dipastikan usaha itu akan terancam gagal. Pendapat Situmorang (2011) menekankan pentingnya sebuah modal dalam mempengaruhi keberhasilan suatu usaha.

Pemberian modal usaha senilai Rp. 250.000,00, menurut peserta didik dirasakan masih kurang untuk memulai sebuah usaha baru, namun seiring berjalannya koperasi, peserta didik merasa sadar bahwa koperasi itu berguna untuk membantu peserta didik saat kekurangan modal, karena peserta didik juga mengakui peserta didik tidak dapat mengendalikan modal Rp. 250.000,00 dengan baik, karena terkadang modal tersebut tersorok untuk membeli kebutuhan rumah tangga, dan disaat modal peserta didik habis koperasi simpan pinjam dirasakan sebagai solusi dalam permodalan.

Namun manfaat koperasi bagi peserta didik tidak hanya sampai disitu, karena pada saat dana penguatan manajemen vokasi tahun 2015 ini belum bisa dicairkan karena terbentur adanya peraturan pemerintah, yang seperti biasanya untuk pencairan dana hanya cukup dengan akta notaris dari tingkat Kabupaten, sekarang pencairan dana mengharuskan semua lembaga mempunyai ijin dari Kementrian Hukum dan HAM, koperasi yang didirikan pengelola, hadir untuk mengajarkan kepada warga masyarakat agar tidak tergantung pada dana dari pemerintah. Dengan adanya susahnya pencairan dana, tidak membuat peserta didik mengalami kemacetan usaha.

Tidak bisa dipungkiri bahwa kegiatan pelatihan kewirausahaan Desa Vokasi merupakan program yang perencanaannya bersifat top down. Top down planning adalah model perencanaan yang dilakukan dari atasan yang ditujukan kepada bawahannya dimana yang mengambil keputusan adalah atasan sedangkan bawahan hanya sebagai pelaksana saja. Dalam pengertian lain terkait dengan pemerintahan, perencanaan top down planning atau perencanaan atas adalah perencanaan yang dibuat oleh pemerintah ditujukan kepada masyarakat dimana masyarakat sebagai pelaksana saja. Jadi semua pendanaan dari alokasi biaya pelatihan dan pemberian modal sudah dialokasikan sesuai dengan perencanaan pemerintah, dan begitu pendanaan dari pemerintah macet atau mengalami masalah, maka akan berdampak pada terjadinya kemacetan atau kegagalan program.

Karena itu dengan berjalannya pembentukan koperasi diharapkan dapat mengurangi ketergantungan terhadap anggaran pemerintah, meningkatkan kemandirian warga belajar kelompok boga dalam melaksanakan aktivitas usahanya, karena melalui koperasi simpan pinjam, pengelola juga 


\section{Jurnal Pendidikan dan Pemberdayaan Masyarakat, 4 (2), November 2017 - 138}

Norma Laili Ikhsan

mendidik warga belajar degan memberlakukan simpanan wajib sebesar Rp. 5000,00 untuk setiap anggota, setiap bulannya yang dibayar saat pertemuan rutin setiap tanggal 19 disetiap bulan dan boleh diambil pada saat peserta didik kekurangan modal. Selain itu pengelola juga mengenakan denda senilai Rp.10.0oo,oo yang nantinya akan dimasukan ke kas koperasi bagi warga belajar yang tidak mengikuti kegiatan pembinaan setiap bulannya. Selain itu kumpulan dana denda yang disimpan koperasi tersebut nantinya akan digunakan untuk membantu peserta didik, apabila diantara peserta didik ada yang sakit. Penanaman kedisiplinan dan ketidaktergantungan pada dana dari pemerintah dan nilai sikap paling peduli antara anggota menjadi nilai lebih pada kelompok pelatihan kewirausahaan tata boga Desa Vokasi Grujugan yang bisa digunakan sebagai acuan bagi kelompok program Desa Vokasi lainnya yang mengalami masalah dalam pendanaan.

Pembangunan menurut Alexander (1994) dalam (Ahmed, 2010, p.27) pada dasarnya merupakan suatu proses perubahan yang melibatkan masyarakatnya, seluruh struktur ekonomi sosial, budaya, politik dan fisik, serta sistem nilai dan cara hidup. Pada intinya pembangunan masyarakat merupakan suatu upaya yang mengarah pada kemajuan (progres) masyarakat dan peningkatan kesejahteraan sosial-ekonomi, baik di perkotaan maupun di perdesaan. Pada tahap pembangunan ekonomi, menurut teori pertumbuhan ekonomi yang dikemukakan oleh Schumpeter (1942) dalam Arifin, Hadi, \& Alma (2007, p. 16), yang menjelaskan bahwa pertumbuhan ekonomi sangat ditentukan oleh kemampuan wirausaha (entrepreneurship). Sebab merekalah yang memiliki kemampuan dan kebernian mengaplikasikan penemuan baru (inovasi) dalam aktivitas produksi. Dengan terciptanya wirausaha baru maka akan terbukanya sebuah lapangan kerja dan pengurangan pengangguran dan peningkatan kesejahteraan. Penelitian yang dilakukan oleh Amoros et al (2011) di negara-negara Amerika Latin membuktikan bahwa tingkat pertumbuhan kewirausahaan dapat meningkatkan indikator daya saing mereka yang kemungkinan menjadi faktor kunci dalam mencapai tahap pembangunan selanjutnya. Dengan kata lain, negara-negara yang memiliki faktor kewirausahaan positif akan memiliki daya saing yang positif

Salah satu cara untuk meningkatkan jumlah wirausaha antara lain dengan melalui program pelatihan kewirausahaan. Terlebih lagi pada orientasi pembangunan perdesaan, pelatihan kewirausahaan dengan berorientasi pada pengembangan potensi lokal wilayah dirasa sangat perlu dilakukan.

Nibeza (2015, p. 105) menjelaskan bahwa pembangunan perdesaan bertujuan untuk mengatasi kebutuhan sebagian besar penduduk dan memastikan pengurangan kemiskinan yang berkelanjutan danmata pencaharian perdesaan. Dari uraian tersebut dengan diadakaannya program pelatihan kewirausahaan diharapkan akan memberikan sebuah pendidikan dan ketrampilan life skill di bidang wirausaha dengan memanfaatkan potensi lokal wilayah perdesaan mengurangi tingkat kemiskinan dan membuka mata pencahariaan baru bagi masyarakat di perdesaan sehingga akan peningkatan kesejahteraan masyarakat desa, terutama dalam hal terpenuhinya kebutuhan sehari-hari seperti papan, sandang, pangan.

Sebagai bentuk pembangunan perdesaan, sejak tahun 2009 pemerintah Provinsi Jawa Tengah terus menggerakan sebuah program untuk masyarakat perdesaan yaitu program Desa Vokasi berbasis Pelatihan kewirausahaan. Program ini dipandang oleh pemerintah sebagai solusi untuk mengatasi pengangguran, kemiskinan, dan terabaikannya potensi sumber daya alam di perdesaan karena banyaknya masyarakat usia produktif yang melakukan urbanisasi, sehingga potensi SDA di perdesaan tidak dapat terolah dengan baik dan berakibat pembangunan di perdesaan berjalan stagnan.

\section{Penilaian Hasil Penerapan Kewirausaha- an Tata Boga di Desa Vokasi Grujugan}

Hasil penelitian menunjukan bahwa peserta didik sudah mengalami peningkatan pengetahuan, ketrampilan, dan perubahan sikap peserta didik dalam kegiatan usaha meliputi Tabel 2. 


\section{Jurnal Pendidikan dan Pemberdayaan Masyarakat, 4 (2), November 2017 - 139}

Norma Laili Ikhsan

Tabel 2.Penilaian Hasil Pelatihan dalam Praktek Kegiatan Usaha Mandiri

\begin{tabular}{|c|c|c|}
\hline No. & Aspek Penilaian & $\begin{array}{c}\text { Penilaian Hasil Dari } \\
\text { Perkembangan } \\
\text { Peserta didik }\end{array}$ \\
\hline 1. & $\begin{array}{l}\text { Visi dan Tujuan } \\
\text { Usaha; }\end{array}$ & $\begin{array}{l}\text { Sudah memiliki visi dan } \\
\text { tujuan usaha yang jelas } \\
\text { dengan berorientasi ke } \\
\text { masa depan, pandangan } \\
\text { ke depan }\end{array}$ \\
\hline 2. & $\begin{array}{l}\text { Keberanian } \\
\text { menerima dan } \\
\text { menghadapi } \\
\text { resiko. }\end{array}$ & $\begin{array}{l}\text { Kurang mempunyai } \\
\text { usaha untuk } \\
\text { menimbang dan } \\
\text { menerima risiko baik } \\
\text { waktu ataupun uang } \\
\text { dan dalam resiko } \\
\text { mengambil keputusan } \\
\text { dan menghadapi } \\
\text { ketidakpastian. }\end{array}$ \\
\hline 3. & $\begin{array}{l}\text { Perencanaan dan } \\
\text { Pendampingan } \\
\text { usaha }\end{array}$ & $\begin{array}{l}\text { Mempunyai } \\
\text { perencanaan yang } \\
\text { matang dan } \\
\text { pendampingan usaha } \\
\text { yang baik }\end{array}$ \\
\hline 4. & $\begin{array}{l}\text { Pengorganisasian } \\
\text { usaha; }\end{array}$ & $\begin{array}{l}\text { Sudah cukup baik } \\
\text { mengorganisasikan } \\
\text { usaha (koordinasi } \\
\text { usaha) }\end{array}$ \\
\hline 5. & $\begin{array}{l}\text { Menjalankan } \\
\text { Usaha dan Inovasi; }\end{array}$ & $\begin{array}{l}\text { Sudah cukup baik } \\
\text { dalam menjalankan } \\
\text { usaha (menjaga } \\
\text { kelancaran usaha dan } \\
\text { memiliki usaha dan } \\
\text { dalam menciptakan, } \\
\text { menemukan dan } \\
\text { menerima ide-ide baru. }\end{array}$ \\
\hline 6. & $\begin{array}{l}\text { Pengawasan dan } \\
\text { Evaluasi Usaha }\end{array}$ & $\begin{array}{l}\text { Mampu mengawasi } \\
\text { (monitoring) dan } \\
\text { mengevaluasi usaha } \\
\text { dengan cukup baik }\end{array}$ \\
\hline 7. & $\begin{array}{l}\text { Bekerja keras } \\
\text { sesuai dengan } \\
\text { tingkat } \\
\text { kepentingan; }\end{array}$ & $\begin{array}{l}\text { Bekerja keras sesuai } \\
\text { dengan tingkat } \\
\text { kepentingan dengan } \\
\text { baik }\end{array}$ \\
\hline 8. & $\begin{array}{l}\text { Pengembangan } \\
\text { hubungan dengan } \\
\text { mitra usaha; }\end{array}$ & $\begin{array}{l}\text { Sudah baik dalam } \\
\text { mengembangkan } \\
\text { hubungan dengan mitra } \\
\text { usaha (pelanggan, } \\
\text { pemasok, pekerja dan } \\
\text { pihak lain) }\end{array}$ \\
\hline 9. & $\begin{array}{l}\text { Tanggung jawab } \\
\text { terhadap } \\
\text { keberhasilan dan } \\
\text { kegagalan usaha }\end{array}$ & $\begin{array}{l}\text { Bertanggung jawab } \\
\text { terhadap keberhasilan } \\
\text { dan kegagalan usaha } \\
\text { dengan baik }\end{array}$ \\
\hline 10. & Kepemimpinan & $\begin{array}{l}\text { Dapat memotivasi, } \\
\text { melaksanakan dan } \\
\text { mengarahkan tujuan } \\
\text { usaha dengan baik. }\end{array}$ \\
\hline
\end{tabular}

Sumber: Diolah dari data primer tahun 2016.
Dari hasil Tabel 2 menunjukan perubahan sikap, perilaku dan pengetahuan dan keterampilan peserta didik yang meliputi (1) peserta didik sudah memiliki visi dan tujuan usaha yang jelas (baik); (2) kemampuan dalam perencanaan (promosi dan strategi pemasangan harga) dan pendampingan usaha sudah baik; (3) kemampuan dalam mengorganisasikan (koordinasi) usaha cukup baik; (4) kemampuan dalam menjalankan usaha cukup baik, dan inovasi sudah baik; (5) kemampuan dalam mengawasi dan mengevaluasi usaha sudah cukup baik; (6) bekerja keras sesuai dengan tingkat kepentingan dengan baik; (7) pengembangan hubungan dengan mitra usaha dengan baik; (8) tanggung jawab terhadap keberhasilan dan (9) Sudah mempunyai sikap kepemimpinan yang baik; (10) Keberanian menerima dan menghadapi resiko peserta didik terlihat masih kurang baik.

Pelaksanaan suatu program pelatihan dan pembinaan dapat dikatakan berhasil apabila dalam diri para peserta pelatihan dan pengembangan tersebut terjadi suatu proses transformasi. Proses transformasi tersebut dapat dinyatakan berlangsung dengan baik apabila terjadi paling sedikit dua hal, yaitu: (a) Peningkatan kemampuan dalam melaksanakan tugas, (b) Perubahan perilaku yang tercermin pada sikap, disiplin dan etos kerja. Untuk mengetahui terjadi tidaknya perubahan tersebut dilakukan penailaian. Penilaian ditujukan bukan saja pada hal-hal teknis juga pada keperilakuan (Siagian, 2002, p. 202). Hal tersebut dipertegas oleh Tristanti \& Suryono (2014, p. 123) "Keberhasilan program keterampilan ditunjukkan oleh perubahan perilaku warga".

Hasil penelitian dalam penilaian kegiatan usaha, upaya penilaian penerapan hasil pelatihan kewirausahaaan tata boga desa vokasi dilakukan sesuai dengan teori Siagian dengan menilai kemampuan dan pengamatan perubahan perilaku peserta didk dalam menjalankan kegiatan usaha mandiri melalui metode seperti observasi, wawancara, pemantauan perilaku peserta didik dalam kegiatan praktek usaha mandiri. Penilaian praktek kegiatan usaha mandiri ditunjukan melalui peningkatan kemampuan dalam melaksanakan usaha dan per- 


\section{Jurnal Pendidikan dan Pemberdayaan Masyarakat, 4 (2), November 2017 - 140}

Norma Laili Ikhsan

ubahan perilaku yang tercermin pada langkah-langkah peserta didik sebagai upaya mempraktekan kemampuannya setelah selesai mengikuti kegiatan pelatihan kewirausahaan tata boga untuk menjadi seorang wirausaha menggunakan indikator penelitian sesuai dengan teori Steinhoff \& Burges dan Dusselman jika digabungkan sebagai berikut:

Menurut Steinhoff \& Burges dalam Suryana (2006, p. 66) mengemukakan bahwa langkah untuk menjadi wirausaha atau jadi pengusaha yang sukses pertama-tama harus memiliki visi dan tujuan yang jelas, kemudian ada kemauan dan keberanian untuk menghadapi resiko baik waktu maupun uang. Langkah selanjutnya adalah dengan membuat perencanaan usaha, mengorganisasikan dan menjalankannya. Agar usaha tersebut berhasil, selain harus memiliki kerja keras sesuai dengan ungenerasinya, wirausaha harus mampu mengembangkan hubungan baik dengan mitra usaha maupun semua pihak yang terkait dengan kepentingan perusahaan dan harus bertanggung jawab terhadap keberhasilan dan kegagalan usahanya.

Menurut Dusselman (1989, p. 16), dalam Suryana (2006, pp. 50-51) seorang yang memiliki jiwa kewirausahaan ditandai oleh pola-pola tingkah laku yang ditunjukan dalam indikator langkah-langkah sebagai berikut: (a) Inovasi, yaitu usaha untuk menciptakan, menemukan, dan menerima ideide baru; (b) Keberanian untuk menghadapi risiko, yaitu usaha untuk menimbang dan menerima risiko dalam mengambil keputusan dan menghadapi ketidakpastian; (c) Kemampuan manajerial meliputi perencanaan, koordinasi, menjaga kelancaran usaha dan mengawasi dan mengevaluasi usaha; (d) Kepemimpinan, yaitu usaha memotivasi, melaksanakan, dan mengarahkan tujuan usaha.

Dari hasil penelitian, penialian peserta didik melalui mengamatan sikap dan tingkah laku dalam melaksanakan kegiatan usaha mandiri belum semuanya sesuai teori sudah yang dikemukakan oleh Steinhoff \& Burges dan Dusselman, ada satu kekurangan yaitu dalam hal kemampuan mengambil resiko yang dinilai masih kurang. Tapi secara keseluruhan peserta didik sudah mulai menunjukan purubahan perilaku, sikap, pengetahuan, keterampilan dan mengalami kemajuan. Kemampuan peserta didik dalam menerima dan menghadapi resiko dalam hasil penelitian ini dirasakan masih kurang.

Dalam menjalankan kegiatan usaha peserta didik belum mempunyai kemauan untuk menambah hasil produksi makanan yang mereka buat karena modal yang terbatas. Mereka juga belum mau meminjam dana ke Bank dalam jumlah besar untuk memperluas usaha dengan menambah produksi, dengan alasan takut untuk meminjam uang karena usaha mereka masih kecil dan peserta didik masih takut tidak bisa mengembalikan uang yang mereka pinjam. Selain itu peserta didik juga takut dananya tersorok untuk membiayai kebutuhan pribadi dan takut jumlah pesanannya berkurang sehingga nantinya bisa membuat usahanya macet.

Sikap peserta didik yang kurang percaya diri dan optimisme dalam mengambil resiko akan membuat peserta didik tidak akan berkembang lebih sukses. Hal ini seperti yang dijelaskan Drucker (Alma, 2011, p. 57), yang menjelaskan bahwa optimisme dan keberanian mengambil resiko dalam menghadapi suatu tantangan tidak luput dari pengaruh kepercayaan diri yang ada. Sikap optimisme dan keberanian mengambil resiko didasarkan atas perhitungan yang benar-benar matang dan disesuaikan dengan tingkat kepercayaan diri yang ada. Semua tantangan harus dihadapi dengan penuh perhitungan. Keberanian yang tinggi dengan perhitungan akan dapat membuahkan kesuksesan.

Walaupun kemampuan peserta didik dalam mengambil resiko masih kurang, tapi peserta didik sudah memperlihatkan perubahan pengetahuan, sikap dan perilaku setelah mengikuti kegiatan pelatihan, yang ditunjukan dalam kemampuan mereka dalam berwirausaha memproduksi makanan yang sudah berjalan dari 2010-2016, walaupun usahanya masih dalam sekala kecil. 
Jurnal Pendidikan dan Pemberdayaan Masyarakat, 4 (2), November 2017 - 141

Norma Laili Ikhsan

\section{Faktor yang Mempengaruhi Pelaksanaan Program Pelatihan Kewirausahaan Tata Boga di Desa Vokasi Grujugan}

Tabel 3. Hasil Penelitian Faktor yang Mempengaruhi Pelaksanaan Program Pelatihan Kewirausahaan Tata Boga di Desa Vokasi Grujugan

\begin{tabular}{|c|c|c|}
\hline No. & Faktor & Hasil di Lapangan \\
\hline 1. & $\begin{array}{l}\text { Motivasi dan } \\
\text { Kesungguhan dalam } \\
\text { berusaha; }\end{array}$ & $\begin{array}{l}\text { Peserta didik dari awal proses pembelajaran dan usaha mandiri mereka } \\
\text { selalu semangat dan memiliki motivasi yang tinggi, karena mereka } \\
\text { punya tujuan untuk dapat melakukan kegiatan usaha mandiri guna } \\
\text { mendapatkan modal tambahan, karena itu mereka selalu sungguh- } \\
\text { sungguh dalan dalam menjalankan usahanya untuk produksi olahan } \\
\text { berbagai jenis makanan. }\end{array}$ \\
\hline 2. & $\begin{array}{l}\text { Perencanaan dan } \\
\text { pendampingan usaha; }\end{array}$ & $\begin{array}{l}\text { Memiliki perencanaan yang matang seperti sudah mempunyai } \\
\text { perencanaan meliputi: (a) perencanaan lokasi usaha; (b) perencanaan } \\
\text { pengelolaan keuangan; (c) perencanaan strategi usaha; dan (d) } \\
\text { perencanaan strategi pemasaran (promosi dan pemasangan harga). }\end{array}$ \\
\hline 3. & $\begin{array}{l}\text { Kemampuan mengenal } \\
\text { peluang, kesempatan, } \\
\text { dan kompetitor. }\end{array}$ & $\begin{array}{l}\text { Peserta didik sudah bisa mengenal peluang, dengan aktif mengkuti } \\
\text { pameran sesa vokasi. Selain itu peserta didik juga selalu memanfatkan } \\
\text { peluang dari kunjungan lembaga dinas kecamatan, kabupaten atau } \\
\text { provinsi yang mengadakan kunjungan ke Desa Vokasi Grujugan untuk } \\
\text { mempromosikan hasil makanan kelompok boga. Sudah punya PIRT } \\
\text { untuk merambah pasar yang lebih luas. }\end{array}$ \\
\hline 4. & Lokasi usaha & $\begin{array}{l}\text { Usaha produksi berbagai jenis makanan dilakukan dirumah masing- } \\
\text { masing secara home industry. Dan untuk lokasi pemasaran usaha kalau } \\
\text { ada pesanan dari supermarket dan tokoh oleh-oleh atau pameran, } \\
\text { dikoordinir jadi satu dalam kelompok. Tapi kalau tidak ada pesanan, } \\
\text { peserta didik memasarkan sendiri-sendiri hasil produksi makanan yang } \\
\text { dibuat lewat warung atau pasar. }\end{array}$ \\
\hline 5. & Pengawasan peralatan & $\begin{array}{l}\text { Peserta didik telah mampu dalam melakukan pengawasan terhadap } \\
\text { peralatan yang dimiliki, karena peralatan produksi membuat berbagai } \\
\text { olahan jenis makanan itu masih berupa peralatan sederhana seperti } \\
\text { membuat jipang beras ketan yang hanya membutuhkan cetakan jipang, } \\
\text { wajan, kompor, pisau, baskom. }\end{array}$ \\
\hline 6. & $\begin{array}{l}\text { Pengalaman, } \\
\text { kemampuan } \\
\text { manajerial dan SDM; }\end{array}$ & $\begin{array}{l}\text { Usaha produksi berbagai olahan makanan yang dilakukan peserta didik } \\
\text { merupakan pengalaman usaha pertama, karena itu pengalaman yang } \\
\text { dimiliki peserta didik masih rendah karena hanya diperoleh saat } \\
\text { pelatihan. }\end{array}$ \\
\hline 7. & $\begin{array}{l}\text { Kurangnya modal dan } \\
\text { kemampuan mengatur } \\
\text { aliran kas }\end{array}$ & $\begin{array}{l}\text { Modal terbatas hanya Rp. } 250.000,00 \text { bagi peserta didik masih kurang. } \\
\text { Selain itu peserta didik juga belum mampu mengendalikan keuangan, } \\
\text { kadang-kadang modal yang terbatas itu tersorok untuk memenuhi } \\
\text { kebutuhan sehari-hari, sehingga harus meminjam modal tambahan dari } \\
\text { koperasi kelompok Tata Boga. }\end{array}$ \\
\hline 8. & $\begin{array}{l}\text { Kemampuan } \\
\text { menerima dan } \\
\text { menghadapi resiko. }\end{array}$ & $\begin{array}{l}\text { Belum mempunyai keberanian dalam menambah jumlah produksi } \\
\text { dengan meminjam modal lebih besar. }\end{array}$ \\
\hline
\end{tabular}

Sumber: diolah dari data primer 2016.

Faktor yang mempengaruhi penerapan hasil pelatihan kewirausahaan tata boga oleh peserta didik dalam kegiatan usaha dipengaruhi oleh dua faktor yang bersifat mendukung dan faktor yang bersifat menghambat. Faktor yang mempengaruhi tersebut disusun oleh penulis dari tingkatan yang berpengaruh paling tinggi sampai tingkatan berpengaruh paling tendah. Faktor yang mem- pengaruhi penerapan hasil pelatihan kewirausahaan tata boga oleh peserta didik dalam kegiatan usaha yang bersifat mendukung yaitu:

Dalam menerapkan hasil pelatihan kewirausahaan tata boga oleh peserta didik yang telah selesai mengikuti proses kegiatan pembelajaran dan pelatihan tata boga di Desa Vokasi Grujugan, terdapat beberapa 


\section{Jurnal Pendidikan dan Pemberdayaan Masyarakat, 4 (2), November 2017 - 142}

Norma Laili Ikhsan

faktor yang bersifat mendukung dan menghambat yang penerapan hasil pelatihan kewirausahaan tata boga. Faktor-faktor tersebut meliputi tersebut meliputi:

Menurut Zimmerer dalam Suryana (2006, pp. 68-69), mengemukakan beberapa faktor yang menyebabkan wirausaha gagal dalam menjalankan usaha barunya, diantaranya: (a) Tidak kompeten dalam menajerial.; (b) Kurang berpengalaman; (c) kurang dapat mengendalikan keuangan; (d) gagal dalam perencanaan; (e) lokasi yang kurang memadai; (f) kurangnya pengawasan peralatan; (g) sikap yang kurang sunguh-sungguh dalam berusaha. Uraian faktor tersebut sebagai berikut:

Hasil penelitian menjelaskan bahwa dalam menerapkan hasil pelatihan kewirausahaan tata boga oleh peserta didik yang telah selesai mengikuti proses kegiatan pembelajaran dan pelatihan tata boga di Desa Vokasi Grujugan, terdapat beberapa faktor yang bersifat mendukung dan menghambat yang penerapan hasil pelatihan kewirausahaan tata boga. Faktor-faktor tersebut meliputi tersebut meliputi:Faktor yang mempengaruhi peserta didik yang sifatnya mendukung peserta didik dalam menjalankan kegiatan usaha untuk kelima faktor lain meliputi (1) motivasi dan kesungguhan dalam berusaha; (2) perencanaan (promosi dan strategi pemasangan harga) dan pendampingan usaha; (3) kemampuan mengenal peluang, kesempatan, dan kompetitor (pesaing bisnis); (4) lokasi usaha; (5) pengawasan peralatan. merupakan faktor yang bersifat mendukung pelatihan kewirausahaan tata boga Desa Vokasi Grujugan. Faktor mempengaruhi beserta didik yang sifatnya mennghambat meliputi (1) Kurangnya pengalaman, kemampuan manajerial dan SDM; (2) Kurangnya modal dan kurangnya kemampuan mengatur aliran kas sebagai faktor yang menghambat pada pelatihan kewirausahaan kerajinan tata boga desa vokasi.

Namun ada satu faktor yang ditemukan di lapangan yang tidak sesuai dengan beberapa teori yang dikemukakan diatas yaitu faktor kemampuan menerima dan menghadapi resiko yang kurang baik dari peserta didik yang berakibat pada usaha peserta didik yang masih tetap kecil karena mereka tidak mau menambah produksi, dengan alasan jika peserta didik takut memperbesar usahanya melalui peminjaman modal lebih besar ke Bank/lembaga keungan lainnya. Sehingga indikator kemampuan menerima dan menghadapi resiko menjadi faktor tambahan ketiga yang menghambat peserta didik dalam pelaksanaan kegiatan usaha. Padahal keberanian dalam menghadapi resiko akan dapat membuahkan kesuksesan, seperti yang dikemukakan Drucker dalam Alma (2011, p. 57) Optimisme dan keberanian mengambil resiko dalam menghadapi suatu tantangan tidak luput dari pengaruh kepercayaan diri yang ada. Sikap optimisme dan keberanian mengambil resiko didasarkan atas perhitungan yang benar-benar matang dan disesuaikan dengan tingkat kepercayaan diri yang ada. Semua tantangan harus dihadapi dengan penuh perhitungan. Keberanian yang tinggi dengan perhitungan akan dapat membuahkan kesuksesan.

Hasil penelitian menunjukan bahwa pelaksanaan program pelatihan kewirausahaan tata boga desa vokasi sudah memberi dampak cukup baik bagi sasaran program pelatihan. Hasil penelitian dampak tersebut diuraikan pada Tabel 3.

Dalam pembuatan kebijakan program desa vokasi, sebelumnya Tim Direktorat Pengembangan Kursus dan Pelatihan (2011, p. 8) sudah membuat empat indikator untuk mengetahui dampak dari keberhasilan program desa vokasi. Indikator keberhasilan tersebut dalam meliputi: (1) Minimal 9o\% peserta didik belajar tuntas mengikuti program Desa Vokasi; (2) Minimal 70\% lulusan mampu berwirausaha/berusaha mandiri; (3) Produk barang/jasa hasil program Desa Vokasi laku dipasarkan (marketable); (4) Berkurangnya angka pengangguran di desa setempat. 


\section{Jurnal Pendidikan dan Pemberdayaan Masyarakat, 4 (2), November 2017 - 143}

Norma Laili Ikhsan

\section{Dampak Pelaksanaan Program Pelatihan Kewirausahaan Tata Boga di Desa Vokasi Grujugan}

Tabel 4. Hasil Penelitian Dampak Pelaksanaan Pelatihan Kewirausahaan Tata Boga

\begin{tabular}{|c|c|c|}
\hline No. & Hasil Penelitian & Outcome \\
\hline 1. & $\begin{array}{l}\text { 2o Peserta didik kelompok pelatihn tata boga lulus } \\
\text { mengikuti pembelajaran dan mendapatkan sertifikat } \\
\text { kelulusan dengan nilai yang memuaskan. }\end{array}$ & $\begin{array}{l}\text { Perubahan sikap, Peningkatan } \\
\text { Pengetahuan, Ketrampilan }\end{array}$ \\
\hline 2. & $\begin{array}{l}20 \text { Peserta didik bisa menerapkan hasi pelatihan } \\
\text { dalam kegiatan usaha mandiri (berwirausaha) dari } \\
\text { tahun } 2010 \text { sampai } 2016 \text { dengan pendapatan bulanan } \\
\text { antara Rp. 500.00o,oo sampai Rp. 6oo.ooo,oo. }\end{array}$ & $\begin{array}{l}\text { Peningkatan kemampuan berwirausaha } \\
\text { peningkatan status sosial warga belajar } \\
\text { dari menganggur menjadi wirausaha; } \\
\text { peningkatan pendapatan. }\end{array}$ \\
\hline 3. & $\begin{array}{l}\text { Produk hasil desa vokasi pemasarannya sudah } \\
\text { mencapai supermarket di Kabupaten Banyumas, } \\
\text { seperti Moro Swalayan, dan Pusat toko oleh-oleh. }\end{array}$ & $\begin{array}{l}\text { Produk barang/jasa hasil program Desa } \\
\text { Vokasi laku dipasarkan (marketable) }\end{array}$ \\
\hline 4 . & $\begin{array}{l}\text { Terbentuknya lembaga koperasi untuk melatih } \\
\text { kemandirian warga belajar, agar mandiri dan tidak } \\
\text { mengandalkan dana bantuan pemerintah }\end{array}$ & Terbukanya lembaga koperasi \\
\hline 5 . & $\begin{array}{l}\text { Terciptanya solidaritas, perasaan kebersamaan dan } \\
\text { kepedulian antar sesama anggota dan pengurus } \\
\text { pelatihan kewirausahaan tata boga desa vokasi }\end{array}$ & Peningkatan aspek sosial \\
\hline
\end{tabular}

Sumber: diolah dari data primer tahun 2016.

Hasil penelitian menunjukan bahwa dampak dari pelaksanaan pelatihan kewirausahaan desa vokasi sudah memberi dampak sesuai dengan indikator keberhasilan desa vokasi yang dikemukakan oleh Tim Direktorat Pengembangan Kursus dan Pelatihan (2011, p.8) dengan memberi dampak (1) Semua peserta didik belajar tuntas mengikuti program Desa Vokasi yang ditunjukan dengan nilai yang bagus dan sertifikat kelulusan; (2) Keduapuluh lulusan mampu berwirausaha/berusaha mandiri dari tahun 2010-2016; (3) Produk barang/jasa hasil program Desa Vokasi laku dipasarkan (marketable); (4) Berkurangnya angka pengangguran di desa Grujugan karena sasaran pelatihan kedua puluh peserta didik kelompok pelatihan kewirausahaan tata bogo semua berhasil mengembangkan kemampuan yang mereka peroleh untuk membuka kegiatan usaha secara home industry dari 210-2016.

Selain dampak tersebut Garavan dan Barra (1994) dalam Rodrigues, Dinis, Do Paço, Ferreira, \& Raposo (2013, p. 88) menyatakan bahwa tujuan yang paling sering disebut pendidikan dan pelatihan kewirausahaan program adalah sebagai berikut: (a) untuk mendapatkan pengetahuan yang berguna dari kewiraswastaan; (b) untuk memperoleh keterampilan dalam penggunaan teknik, dalam analisis bisnis atmosfer,

dan dalam sintesis rencana aksi; (c) untuk mengidentifikasi dan merangsang keterampilan kewirausahaan; (d) untuk nmengembangkan empati dan dukungan untuk semua aspek kewiraswastaan; (e) mengembangkan sikap terhadap perubahan dan ketidakpastian; dan (f) untuk mendorong mulainya hal baru baru (inovasi).

Hasil penelitian menunjukan bahwa dampak dari tujuan pemikiran Garavan dan Barra (1994) juga sudah dirasakan pada kelompok pelatihan kewirausahaan tata boga desa vokasi Grujugan dengan adanya dampak peningkatan pengetahuan, sikap dan ketrampilan berwirausaha pada kelompok tata boga Desa Vokasi Grujugan.

Selain dampak diatas ada dampak lain yang dirasakan kelompok pelatihan kewirausahaan tata boga desa vokasi Grujugan, meliputi: (a) dari aspek akses usaha, terbukanya lembaga simpan pinjam "koperasi kelompok boga"; (b) dari aspek status sosial, terjadi peningkatan status sosial Desa Grujugan sebagai desa vokasi yang keberadaannya sudah mulai dikenal masyarakat, selain itu terjadi juga peningkatan status sosial bagi warga belajar tata boga dari pengangguran menjadi wirausaha pada kelompok tata boga; (c) dari aspek ekonomi, terjadi peningkatan pendapatan bagi warga belajar, yang ditunjukan dengan jumlah pendapatan pe- 


\section{Jurnal Pendidikan dan Pemberdayaan Masyarakat, 4 (2), November 2017 - 144}

Norma Laili Ikhsan

serta didik antara Rp 500.000 sampai Rp. 60o.0oo/bulan; dan (d) dari aspek sosial terciptanya solidaritas, perasaan kebersamaan dan kepedulian antar sesama anggota dan pengurus pelatihan kewirausahaan tata boga desa vokasi.

Hal tersebut dipertegas oleh hasil penelitian Malik \& Dwiningrum (2014, p. 132) yang menjelaskan bahwa dampak dari peningkatan pemberdayaan melalui program desa vokasi antara lain peningkatan pendapatan, terbukanya akses terhadap pinjaman modal dari lembaga keuangan baik Bank ataupun Non Bank, dan peningkatan status sosial

Dalam upaya membangung perdesaan dan menjadikan masyarakat dididalamnya mampu berdaya dan mandiri, pelaksanaan pelatihan kewirausahaan desa vokasi diharapkan mampu memberikan manfaat terhadap masyarakat diperdesaan sesuai dengan tujuan utama pembangunan perdesaan yaitu strategi untuk memungkinkan kelompok tertentu masyarakat. Ini melibatkan membantu termiskin di antara mereka yang mencari penghidupan di daerah perdesaan untuk menuntut dan mengendalikan lebih dari manfaat pembangunan pedesaan., Chamber (1983) dalam Mtetwa, Dziro, \& Takaza (2013, p. 25). Upaya pelatihan pelaksanaan program pelatihan kewirausahaan desa vokasi sudah memberi dampak cukup baik bagi sasaran program.

\section{SIMPULAN}

Dalam implementasi pelatihan kewirausahaan tata boga Desa Vokasi Grujugan dibagi menjadi empat tahap meliputi tahap persiapan, tahap pelaksanaan kegiatan pelatihan, tahap monitoring dan evaluasi, dan tindak lanjut. Pada pelaksanan program pelatihan kewirausahaan sudah berjalan dengan lancar, walaupun ada beberapa masalah pada tahap tindak lanjut pada masalah dana penguatan manajemen vokasi yang susah dicairkan, namun dapat diatasi dengan baik dengan bantuan pengelolaan dana modal usaha melalui koperasi.

Penilaian hasil penerapan pelatihan kewirausahaan tata boga oleh peserta didik dalam pelaksanaan kegiatan usaha dilakukan melalui pengamatan praktik kegiatan usaha mandiri. Melalui cara ini diperoleh data mengenai sikap peserta didik dalam kegiatan usaha denang peningkatan sikap, keterampilan dan kemampuan dalam melaksanakan kegiatan usaha.

Dampak program pelatihan kewirausahaan tata boga desa vokasi Grujugan yang dirasakan peserta didik kelompok kewirausahaan tata boga, meliputi: (a) dari aspek SDM, terjadi peningkatan pengetahuan ketrampilan dan peningkatan kemampuan berwirausaha. (b) dari aspek akses usaha, terbukanya lembaga simpan pinjam "koperasi kelompok boga"; (c) dari aspek status sosial, terjadi peningkatan status sosial desa grujugan sebagai desa vokasi yang keberadaannya sudah mulai dikenal masyarakat; selain itu terjadi juga peningkatan status sosial bagi warga belajar tata boga dari pengangguran menjadi wirausaha pada kelompok tata boga; (d) dari aspek ekonomi, terjadi peningkatan pendapatan bagi warga belajar; dan (e) dari aspek sosial terciptanya solidaritas, perasaan kebersamaan dan kepedulian antar sesama anggota dan pengurus pelatihan kewirausahaan tata boga desa vokasi.

\section{DAFTAR PUSTAKA}

Alma, B. (2011). Kewirausahaan untuk mahasiswa dan umum. Bandung: Alfabeta.

Arifin, I., Hadi, G., \& Alma, B. (2007). Membuka cakrawala ekonomi. PT Grafindo Media Pratama.

Kementerian pendidikan dan Kebudayaan. (2014). Petunjuk teknis bantuan sosial desa vokasi. Jakarta: Direktorat Jenderal Anak Usia Dini, Nonformal dan Informal Direktorat Pembinaan Kursus dan Pelatihan.

Malik, A., \& Dwiningrum, S. I. A. (2014). Keberhasilan program desa vokasi terhadap pemberdayaan masyarakat di Desa Gemawang Kabupaten Semarang. JPPM (Jurnal Pendidikan Dan Pemberdayaan Masyarakat), 1(2), 124. https://doi.org/10.21831/jppm.vii2.2683

Mtetwa, E., Dziro, C., \& Takaza, S. (2013). Poverty and rural development; tapping from the grassroots. 
Jurnal Pendidikan dan Pemberdayaan Masyarakat, 4 (2), November 2017 - 145 Norma Laili Ikhsan

International Journal of Humanities and Social Science Invention ISSN (Online, 2(5), 21-35. Retrieved from http://www.ijhssi.org/papers/v2(5)/ver sion-4/E2502135.pdf

Nibeza, S. (2015). Entrepreneurship development, a path out of unemployment in Rwanda. International Journal of Research in Economics and Social Sciences, 5(9), 104-121. Retrieved from http://www.euroasiapub.org

Pawito, P. (2008). Penelitian komunikasi kualitatif. Yogyakarta: PT LkiS Pelangi Aksara Yogyakarta.

Rodrigues, R. G., Dinis, A., Do Paço, A., Ferreira, J., \& Raposo, M. (2013). The effect of an entrepreneurial training programme on entrepreneurial traits and intention of secondary students. In T. Burger-Helmchen (Ed.), Entrepreneurship - Born, Made and Educated (pp. 77-92). https://doi.org/10.5772/35302

Siagian, S. P. (2002). Kiat meningkatkan produktivitas kerja. Jakarta: Rineka Cipta.

Situmorang, J. W. (2011). Uji keragaman koperasi berprestasi berdasarkan skala usaha tahun 2009. Jurnal Pengkajian Koperasi Dan UKM, 6(1), 1-23.

Suryana, S. (2006). Kewirausahaan: Pedoman praktis (Kiat dan proses menuju sukses). Jakarta: PT.Salemba Empat.

Syarbaini, S., Rahman, A., Djihado, M., Siagian, S. P., \& Suryana, S. (2002). Sosiologi dan politik. Jakarta: Rineka Cipta. Jakarta: Salemba Empat.

Tristanti, T., \& Suryono, Y. (2014). Evaluasi program kecakapan hidup bagi warga binaan di lembaga pemasyarakatan anak kelas IIA Kutoarjo. JPPM (Jurnal Pendidikan Dan Pemberdayaan Masyarakat), $\quad 1(1), \quad 113-123$. https://doi.org/10.21831/jppm.vii1.2361

Uwameiye, B. E., \& Osho, L. E. (2011). Attitude and motivation as predictors of academic achievement of students in clothing and textiles. Educational Research and Reviews, 6(16), 864-876. https://doi.org/10.5897/ERRo9.141

Tim Direktorat Pengembangan Kursus dan Pelatihan. (2010). Petunjuk teknis percontohan program desa vokasi. Jakarta: Direktorat Pengembangan Kursus dan Pelatihan. 